\title{
Exploring Impact of Macro Economic Variables on GDP of Pakistan
}

\author{
Sidrat Jilani * \\ Dadabhoy Institute of Management Sciences
}

\author{
Farooq-E-Azam Cheema * \\ Institute of Business \& Technology (IBT)
}

Muhammad Asim *

Karachi University Business School

\begin{abstract}
Purpose-This research work explores the impact of macroeconomic variables like inflation, real exchange rate and interest rate on GDP of Pakistan in the light of 32 years data, for the period of 1980 to2013.

Methodology/sample-Research was secondary data based, and multivariate regression analysis was used to analyze the data. Econometric model used for analysis consisted of GDP as dependent variable while the independent variables were interest rate, exchange rate and inflation rate. Data was taken for these variables from the website of State Bank of Pakistan and World Bank. Individual significance of the variables, overall significance and goodness of fit of the econometric model was analysed.

Findings-The study found that there is significant impact of inflation, interest rate and exchange rate on GDP. As far as the signs of co-efficient are concerned, inflation and interest rate had negative relation with GDP while interest rate possessed positive relation with GDP.

Practical implications-Based on results and its analysis it is recommended that Government adopted tight monetary policy to reduce inflation as the results indicate that inflation has significant but negative impact on GDP. In case of developing counties like Pakistan high value of real exchange rate should be maintained because results show that there is significant and positive impact of exchange rate with GDP. Ceiling of interest rate should be removed in order to boost the economy.
\end{abstract}

Keywords :GDP (Gross Domestic Product), Inflation, Rate of Interest and Exchange rate.

\section{PROBLEM BACKGROUND \& AIM OF THE STUDY}

In this study we have examined the impact of some important macroeconomic variables on GDP of Pakistan. GDP, economic health of the country, is affected by many

${ }^{*}$ The material presented by the author does not necessarily portray the viewpoint of the editors and the management of the Institute of Business \& Technology (IBT) or Dadabhoy Institute of Management Sciences and Karachi University Business School.

* Sidrat Jilani : sidratjilani@yahoo.com

*Farooq-E-Azam Cheema : dr.cheema@biztekian.com

* Muhammad Asim : masimku@ @otmail.com

C JMSS is published by the Institute of Business and Technology (IBT). Main Ibrahim Hydri Road, Korangi Creek, Karachi-75190, Pakistan. 
macroeconomic factors like inflation, national income, interest rate, exchange rate etc. Following chart shows many ups and downs in the GDP rate of Pakistan during the ten year period (2002 to 2011). It shows that GDP was encouraged in 2004-06 perhaps because of due to economic reforms by the Musharraf government in the year 2000. In the year 2005, the World Bank named Pakistan the top reformer in its region and among the top 10 reformers globally. Apart from many reasons behind this consistent growth in GDP during this period, low rate of inflation is one of them. During this period the rate of inflation was $7.944 \%$ to $7.921 \%$ which is very low compared to the current rate of inflation. But, the growth in GDP could not remain stable and nosedived in the year 2008-2009 resulting into high rate of unemployment. There were though various reasons behind this decrease in the GDP, prime issue was again the steeply risen rising rate of inflation that soared to $13 \%$ in 2010 .

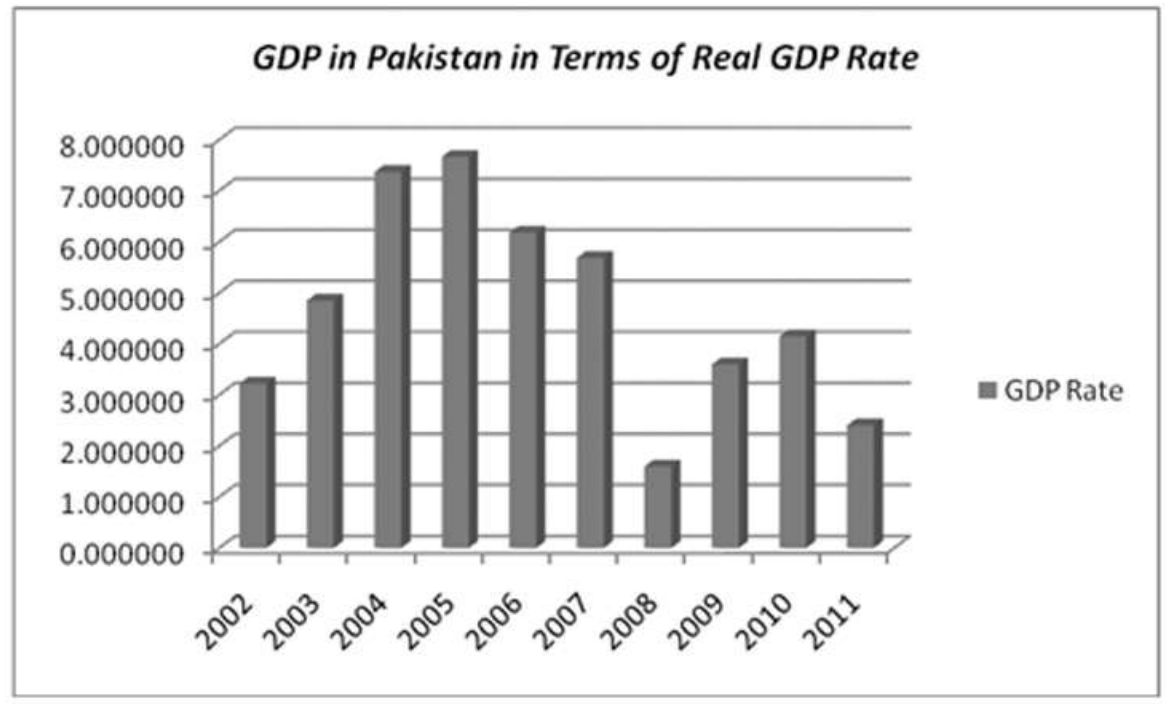

Source: Website of State Bank of Pakistan.

Accordingly, this study is aimed at to find out impact of certain macro-economic factors like inflation, interest rate and real exchange rate on GDP of Pakistan and to find that what steps or measures can be taken by government of Pakistan in order to boost economic growth (GDP) of the country by keeping eyes on these factors. Support was taken from previous studies conducted in this regard. For instance, Cecchetti (2000) concluded in his respective study that inflation possesses negative relationship with GDP while Levy-Yeyati and Sturzenegger, F. (2002) (2002) found that exchange-rate regime affects growth. They said that a linkage between the exchange rate regime and economic growth exists but the sign of the influence over each is not clear. Work of Obamuyi (2009) is significant regarding identification of effect of interest rate over the national growth. The results imply that the behavior of interest rate is important for economic growth in view of the relationships between interest rates and investment on one hand and investment and growth on the other. Studies show that there exists also a unique long-run relationship between economic growth and its determinants, including interest rate.

This paper consists of six sections. In section 2 various relevant studies are reviewed. In section 3 research methodology of the paper is discussed which comprises of description of econometric model, measurement of variables used, the data sources, and the econometric techniques used for this study. The results of the empirical investigation are shown in section 4 . Section 5 consists of critical debate while the conclusions are drawn and recommendations suggested in section 6 . 


\section{LITERATURE REVIEW}

Economic growth of any country can be affected by various macroeconomic variables like inflation, interest rate, exchange rate, national income, govt consumption etc. In this study GDP is symbolized for the economic growth. GDP of any country possesses different relationship with macroeconomic variables. Here, the selected macroeconomic variables are inflation, interest rate and exchange rate.

\subsection{GDP and Inflation}

Various research studies have been carried out in order to find the relationship between inflation and country's growth. The issue has come into existence between structuralist and monetarists in the year 1950s. Structuralists see inflation having a positive role in economic growth while in the eyes of monetarists inflation affects the economic progress negatively. For instance, works of Mallik \& Choudhry (2001) and Bruno \& Easterly (1998) are those works which see inflation harmful to the economic growth of a country. Findings of these works verified the results of Dornbush (1993) who had concluded that there are extreme values which affect the relationship between economic growth and inflation. By extreme values he meant either there exist very high rate of inflation or very low rate of inflation.

Thus, Bruno and Easterly (1998) examined only cases of separate high-inflation with a critical value of 40 per cent and above. They analyzed and concluded that economic growth of any country decreases gravely during high inflation and then get better immediately when there is decrease in inflation. Inflation does not only matter to individuals but it creates difficulties and problems in the whole sector of the economy of a country. De Gregorio (1993) and Barro (1995) also verified the negative relation between economic growth and inflation. In a similar study of Smyth $(1992,1994,1995)$ it was concluded that an increase of one percent in inflation may cause reduction in growth rate by $0.223 \%$. This relationship is negative but insignificant at low rates of inflation; while inflation at higher rate has a significantly negative effect on economic growth. Blejer (2000) and Qayyum (2006) also reached similar conclusions that with the unrelenting high inflation in economy, economic growth of any country suffers and government faces difficulties in running policies smoothly.

Besides reduction in the economic growth, inflation also promotes uncertainty in economy of the country. Due to this risky nature of inflation, central banks over the world have expanded the idea of prime stability and declared it as a major function of monetary policy of the country. Blejer (2000) and Qayyum (2006) also say that monetary policies of the country need to be taken care of since major reason of high inflation in Pakistan is loose monetary policy or in other words excess supply of money growth. They further recommended that Stated Bank of Pakistan should adopted tight monetary policy for low inflation rate. In an article Friedman (1963) wrote about the price stability and stated that the central bank of any country is responsible for this. However, It is disputed that tight monetary control for a longer period of time can decrease high inflation rates. As Goldstein (2002) remarked that a step to over accelerate the economy, through expansion in money circulation or by the currency devaluation will give rise to high inflation rate but does not boost the economy. Accordingly, we assume:

$$
\mathbf{H}_{\mathbf{1}}=\text { There is statically negative significant impact of inflation on GDP }
$$

\subsection{GDP and Interest Rate:}

The relationship between real rate of interest and economic growth is examined by Fry, (1995) and Galbis (1995) who concluded that there is positive and significant 
relationship between real rate of interest and the economic growth. According to a study conducted by World Bank in 1993, the real interest rate was found having significant and a positive impact on growth of the economy in the absence of inflation because when inflation is included, the coefficient on interest rate does not show significant relationship. De Gregorio and Guidotti (1995) concluded that very low value of real interest rate causes financial disturbance in the economy that in turn reduces economic growth. Hence, we propose:

$$
\mathbf{H}_{2}=\text { There is statically significant impact of interest rate on GDP. }
$$

\subsection{GDP and Real Exchange Rate}

There have been certain theories presented propounding a relationship between real exchange rate and country's output in terms of GDP. For instance, Gala (2007), and Bhalla(2007) say that real exchange rate of any country plays a very important role in the process of growth.. However, there is no clear evidence of the effect of exchange rate volatility on the economic growth. Work of Levy-Yeyati (2002) supports this argument and concludes that yes there exist a relationship between exchange rate and country growth but the sign is not clear. Work of Rodrick (2008) is useful in reaching some conclusion in this regard but this work is not taken by the economists as true representative of the world economy since it holds good only for developing counties and does not sufficiently cover the situations of the developed countries. Finally, it is generally agreed that effect of real exchange rate on national economic growth varies from country to country. We propose:

$\mathbf{H}_{\mathbf{3}}=$ There is statically significant impact of Exchange Rate on GDP

\section{METHOD}

This is cause and effect relationship based study wherein GDP (Gross Domestic Product) is the dependent variable while inflation, rate of interest and real exchange rate are the independent variables.

$$
\mathbf{G D P}=\beta_{1}+\beta_{2} \text { Exchange rate }+\beta_{3} \text { Interest rate }+\beta_{4} \text { Inflation }+\mu
$$

Where:

- GDP (gross domestic product) indicates the sum of goods and services produced in the country in one year.

- Inflation shows a consistent rise in price level. In this study, CPI (consumer price index) of Pakistan is taken as measure of inflation.

- Rate of interest is taken as the real one that is the lending interest rate adjusted for inflation.

- Real Effective Exchange rate is used to determine an individual country's currency value relative to the other major currencies in the index, as adjusted for the effects of inflation. All currencies within the said index are the major currencies being traded today: U.S. dollar, Japanese yen, Euro etc.

\subsection{Source of Data}

This research is secondary and time series data based. The study is long term analysis as 32 years data for the period of 1980-2011 was used for this study. The data was collected from the hand book of statistics of State Bank of Pakistan and website of World Bank. The data is arranged in the Table 1 below: 
Table 1

Data of macro-economic variables for the period 1980-2011

\begin{tabular}{|c|c|c|c|c|c|}
\hline S. No & Years & Interest Rate & $\begin{array}{c}\text { Real Effective } \\
\text { Exchange } \\
\text { Rate }\end{array}$ & $\begin{array}{c}\text { GDP } \\
\text { (annual } \\
\text { growth rate) }\end{array}$ & $\begin{array}{c}\text { Inflation } \\
\text { Rate }\end{array}$ \\
\hline $\mathbf{1}$ & $\mathbf{1 9 8 0}$ & -1.40 & 209.47 & 10.22 & 11.94 \\
\hline $\mathbf{2}$ & $\mathbf{1 9 8 1}$ & -5.25 & 237.07 & 7.92 & 11.88 \\
\hline $\mathbf{3}$ & $\mathbf{1 9 8 2}$ & -1.64 & 217.18 & 6.54 & 5.90 \\
\hline $\mathbf{4}$ & $\mathbf{1 9 8 3}$ & 4.44 & 209.77 & 6.78 & 6.36 \\
\hline $\mathbf{5}$ & $\mathbf{1 9 8 4}$ & 0.82 & 214.21 & 5.07 & 6.09 \\
\hline $\mathbf{6}$ & $\mathbf{1 9 8 5}$ & 3.43 & 200.05 & 7.59 & 5.61 \\
\hline $\mathbf{7}$ & $\mathbf{1 9 8 6}$ & 2.95 & 165.06 & 5.50 & 3.51 \\
\hline $\mathbf{8}$ & $\mathbf{1 9 8 7}$ & 2.70 & 145.98 & 6.45 & 4.68 \\
\hline $\mathbf{9}$ & $\mathbf{1 9 8 8}$ & 0.01 & 141.52 & 7.63 & 8.84 \\
\hline $\mathbf{1 0}$ & $\mathbf{1 9 8 9}$ & -4.09 & 132.59 & 4.96 & 7.84 \\
\hline $\mathbf{1 1}$ & $\mathbf{1 9 9 0}$ & 0.76 & 125.39 & 4.46 & 9.05 \\
\hline $\mathbf{1 2}$ & $\mathbf{1 9 9 1}$ & -5.56 & 122.80 & 5.06 & 11.79 \\
\hline $\mathbf{1 3}$ & $\mathbf{1 9 9 2}$ & -3.16 & 120.66 & 7.71 & 9.51 \\
\hline $\mathbf{1 4}$ & $\mathbf{1 9 9 3}$ & -0.12 & 119.19 & 1.76 & 9.97 \\
\hline $\mathbf{1 5}$ & $\mathbf{1 9 9 4}$ & -1.93 & 118.35 & 3.74 & 12.37 \\
\hline $\mathbf{1 6}$ & $\mathbf{1 9 9 5}$ & -2.83 & 117.59 & 4.96 & 12.34 \\
\hline $\mathbf{1 7}$ & $\mathbf{1 9 9 6}$ & 0.51 & 114.47 & 4.85 & 10.37 \\
\hline $\mathbf{1 8}$ & $\mathbf{1 9 9 7}$ & 1.14 & 116.03 & 1.01 & 11.38 \\
\hline $\mathbf{1 9}$ & $\mathbf{1 9 9 8}$ & 4.43 & 113.77 & 2.55 & 6.23 \\
\hline $\mathbf{2 0}$ & $\mathbf{1 9 9 9}$ & 1.96 & 106.02 & 3.66 & 4.14 \\
\hline $\mathbf{2 1}$ & $\mathbf{2 0 0 0}$ & 4.93 & 106.60 & 4.26 & 4.37 \\
\hline $\mathbf{2 2}$ & $\mathbf{2 0 0 1}$ & 4.62 & 97.54 & 1.98 & 3.15 \\
\hline $\mathbf{2 3}$ & $\mathbf{2 0 0 2}$ & 3.20 & 101.04 & 3.22 & 3.29 \\
\hline $\mathbf{2 4}$ & $\mathbf{2 0 0 3}$ & 1.11 & 97.87 & 4.85 & 2.91 \\
\hline $\mathbf{2 5}$ & $\mathbf{2 0 0 4}$ & -2.72 & 97.09 & 7.37 & 7.44 \\
\hline $\mathbf{2 6}$ & $\mathbf{2 0 0 5}$ & -5.60 & 100.00 & 7.67 & 9.06 \\
\hline $\mathbf{2 7}$ & $\mathbf{2 0 0 6}$ & -0.05 & 102.84 & 6.18 & 7.92 \\
\hline $\mathbf{2 8}$ & $\mathbf{2 0 0 7}$ & 0.49 & 101.56 & 5.68 & 7.60 \\
\hline $\mathbf{2 9}$ & $\mathbf{2 0 0 8}$ & -2.51 & 97.74 & 1.60 & 20.29 \\
\hline $\mathbf{3 0}$ & $\mathbf{2 0 0 9}$ & 0.54 & 98.39 & 3.60 & 13.65 \\
\hline $\mathbf{3 1}$ & $\mathbf{2 0 1 0}$ & -0.42 & 103.39 & 4.14 & 13.88 \\
\hline $\mathbf{3 2}$ & $\mathbf{2 0 1 1}$ & 0.22 & 101.55 & 2.40 & 13.90 \\
\hline & & & & & \\
\hline
\end{tabular}

Sources: Website of World Bank and State Bank of Pakistan.

\subsection{Econometric Techniques}

In order to examine relationship between inflation, exchanges rate, interest rate and GDP regression analysis was undertaken. Multivariate regression test was run for that purpose which showed the effects of interest rate, exchange rate, inflation on country's output or GDP. 


\section{RESULTS}

\subsection{Regression Analysis}

In regression analysis, goodness of fit, individual significance and coefficient analysis of each independent variable and overall significance of the model were examined. Through this analysis, $\mathrm{H} 1, \mathrm{H} 2$ and $\mathrm{H} 3$ were also tested.

Table 2

Regression Analysis

\begin{tabular}{|c|c|c|c|c|}
\hline Model & R & R Square & $\begin{array}{c}\text { Adjusted } \\
\text { R Square }\end{array}$ & $\begin{array}{c}\text { Std. Error of } \\
\text { the Estimate }\end{array}$ \\
\hline 1 & $.706(\mathrm{a})$ & .498 & .444 & 1.63517 \\
\hline
\end{tabular}

a Predictors: (Constant), exchange, interest, inflation

In the model summary table, the capital " $\mathrm{R}$ " in shows coefficient of correlation. The coefficient of correlation from the sample data measures the strength direction of a linear relationship between two variables. The range of the correlation coefficient is from -1 to +1 . If there is a strong positive linear relationship between the variables, the value of " $\mathrm{R}$ " will be close to +1 . If there is a strong negative linear relationship between the variables, the value of " $\mathrm{R}$ " will be close to -1 . When there is no linear relationship between the variables or only a weak relationship, the value of " $\mathrm{R}$ " will be close to 0 .

In the above model the value of $\mathrm{R} 2$ is 0.44 which means that $44.4 \%$ of dependent variable - GDP is explained through independent variables which are exchange rate, interest rate and inflation of the country. This value is low because GDP of any country depends on various factors like political stability, government consumption, exports and imports of a country etc.

Table 3

\begin{tabular}{|ll|c|c|c|c|c|}
\hline Model & & $\begin{array}{c}\text { Sum of } \\
\text { Squares }\end{array}$ & df & Mean Square & F & Sig. \\
\hline 1 & Regression & 74.207 & 3 & 24.736 & 9.251 & $.000(\mathrm{a})$ \\
& Residual & 74.866 & 28 & 2.674 & & \\
& Total & 149.073 & 31 & & & \\
\hline
\end{tabular}

a Predictors: (Constant), exchange, interest, inflation b Dependent Variable: gdp

In order to find the overall significance of the model F-Statistics was analyzed. Table 3 above shows that the F- statistics of the model is 9.251 which conclude the econometric model is significant. Individual significance of the variables was determined by their $t$ values. Coefficient analysis of the variables was undertaken by the values of the coefficients of the respective variables.

\subsection{Coefficient Analysis and Individual Significance of the Variables:}




\begin{tabular}{|cl|c|c|c|c|c|}
\hline \multicolumn{2}{|c|}{} & \multicolumn{2}{|c|}{ Unstandardized Coefficients } & $\begin{array}{c}\text { Standardized } \\
\text { Coefficients }\end{array}$ & $\mathrm{t}$ & Sig. \\
\hline & & $\mathrm{B}$ & Std. Error & Beta & & \\
\hline 1 & (Constant) & 3.574 & 1.342 & & 2.663 & .013 \\
& inflation & -.213 & .091 & -.390 & -2.354 & .026 \\
& interest & -.383 & .120 & -.524 & -3.184 & .004 \\
& exchange & .025 & .007 & .492 & 3.615 & .001 \\
\hline
\end{tabular}

a Dependent Variable: GDP

For the inflation rate, $\mathrm{t}$ value remained 2.35 which show that inflation rate has significant impact on GDP, hence $\boldsymbol{H}_{1}$ accepted. For interest rate, $t$ value was found 3.18 which show interest rate has significant impact on GDP, $\boldsymbol{H}_{2}$ also accepted. The t value of exchange rate, last independent variable, was found 3.615 which shows significant impact of exchange rate on GDP, hence $\boldsymbol{H}_{3}$ also accepted.

Analysis of coefficient of inflation rate tells us that there is negative relationship between growth and inflation. It further reveals that $1 \%$ change in inflation rate will bring $39 \%$ change in GDP rate of Pakistan. According to the above equation model it is clear that there is positive relation between exchange rate and GDP. Furthermore, for every $1 \%$ change in exchange rate there on average will be $49.2 \%$ change in GDP by holding other variables constant. From the above model it is also clear that an increase in $1 \%$ of the interest rate there will be decrease in $52.4 \%$ of GDP.

\section{DISCUSSION}

In this study we empirically investigated relationship among interest rate, inflation rate, exchange and GDP in case of Pakistan. The relationship of inflation with GDP was found significant and verifies the results of Dornbush (1993), De Gregorio (1993) and Barro (1995). Our study also verifies the findings of studies of Mallik \& Choudhry (2001) and Easterly (1998) that had concluded that the extremes value of inflation either low or high badly hits the economic growth of the country. Therefore, the central bank should emphasize the price stability in a country and should adopt tight monetary policy. Our results, however, do not conform to the results of study of Smyth (1992, 1994, and 1995). According to findings of these studies, inflation possesses insignificant relationship with economic growth. Whereas our study has concluded that there exists a significant negative relation between inflation and economic growth. It means that an increase in inflation will bring about decrease in economic growth, hence verifying findings of the studies of Blejer (2000) and Qayyum (2006).

Findings of our study show that there is negative but significant relationship between interest rate and GDP which verifies the result of Fry (1995) and Galbis (1995) in terms of significance. But simultaneously our findings contradict the findings of these two studies in terms of direction of relationship. Those studies reveal that there exists positive relationship between economic growth and interest rate whereas our study shows that in case of Pakistan low interest rate boosts the investment which directly effects the economic growth positively.

Our results also verify the work of Rodrik (2008) who concluded that devaluation of currency boosts economc growth in case of developing countries. Likewise, results of our study showed that real exchange rate has significant impact on GDP that verifies the results of (Mann, 1989). 


\section{CONCLUSION AND RECOMMENDATIONS}

In this paper an empirical investigation was made to find out the relationship of inflation, interest rate and exchange rate with GDP. Besides exploring existence and significance of relationship among the GDP and the macroeconomic factors, nature of relationship was also explored. on the basis of the statical examination of the data and results of the analysis it was concluded that in long run all selected variables i.e.interest rate, exchange rate and inflation had significant impact on GDP .

The findings of this study are analogous to the cited literture that there is a significant impact of inflation on economic growth of the country, apprising of effect of low inflation on growth of the economy of country whereas low inflation causes enhancement in savings and high rate of interest on deposits deirectly bring about the increase in lending, the more lending means people will increase their investment which is a positive sign for the economic growth of the country. It is further concluded form the analysis of the data that there is negative relationship between inflation and economic growth in long term. But it disagreed with a study in the cited literature that inflation and economic growth rates are positively related. It is also concluded that inflation's sensitivity to growth is more than that of growth to changes in inflation.

The coefficient of interest rate shows negative relationship with GDP. As it is discussed in literature review that the there is no clear evidence of the relationship between exchange rate and economic growth because it varies from country to country. In this paper I have determined the relationship between exchange rate and economic growth and according to the results I conclude that there is positive and significant relationship between exchange rate and economic growth of Pakistan in long term.

Interest rate should be suitable to produce deposits which directly accomplish the requirements of investments and therefore people have the chance to save their money with the banks instead of investing anywhere else. In order to control inflation Government should take measures because as this research paper concludes that there exists a negative relation between inflation and economic growth therefore to boost the economic growth inflation should be controlled. A tight monetary policy should be used as a measure to control inflation. Besides the various measures to control inflation it is strongly recommended that the Central Bank must lower the printing of money which is an important measure to decrease inflation.

According to this research impact of exchange rate in terms of real exchange rate on economic growth is significant and the relationship is positive with the economic growth therefore high exchange rate should be maintained in order to boost the economic growth.

\section{REFERENCES}

1. Barro, R. J. (1995) Inflation and Economic Growth, Bank of England Quarterly Bulletin 35: 166-176.

2. Bhalla, Surjit S. (2007) Second Among Equals: The Middle Class Kingdoms of India and China. Washington DC: Peterson Institute of International Economics

3. Blejer, M. (2000) Inflation Targetting in Practice: Strategic and operational issues and application to emerging market economies. International Monetary Fund.

4. Bruno, T. \& Easterly, W. (1998) Inflation crises and long-run growth. Journal of Monetary Economics , 3-26.

5. Cecchetti, S. G. (2000) Making Monetary Policy: Objectives and Rules. Oxford Review of Economic Policy 16:4, 43-59. 
6. De Gregorio, Jose. \& Guidotti, P. E. (1995) financial development and economic growth. World Development, Vol. 23(3), pages 433-448

7. Dornbush, R. (1993) Stabilization, Debt and Reform: Policy Analysis for Developing Countries. New York: Harvester Wheatsheaf .

8. Friedman, M. (1963) Inflation: Causes and Consequences. Proquest/Csa Journal Division

9. Fry, M. (1995) Money, Interest, and Banking in Economic Development. Johns Baltimore \& London: Hopkins University Press.

10. Galbis, V. (1995) Financial Sector Reforms in Eight Countries: Issues and Results. IMF Working Paper No. 95/141 .

11. Gala, P. (2002) Real Exchange Rate Levels and Economic Development: Theoretical Analysis and Empirical Evidence, Sao Paulo Business Administration School, Getulio Vargas Foundation, 200

12. Goldstein, M. (2002). Managed Floating Plus. Washington DC: Institute of International Economics

13. Hooper, Peter and Mann, C. (1989) The Emergence And Persistence of the U.S External Imbalance: 1980-1987, Princeton Studies in International finance. New Jersey: Princeton University.

14. Levy-Yeyati, E. and Sturzenegger, F. (2002) To Float or to Fix: Evidence on the Impact of Exchange Rate Regimes on Growth. American Economic Review, 12(2), p.1-49.

15. Mallik, G. and Chowdhury, A. (2001). Inflation and Economic Growth: Evidence from four South Asian Countries. Asia-Pacific Development journal, 13

16. Obamuyi, T. M. (2009) An investigation of the relationship between interest rates and economic growth in Nigeria, 1970 - 2006 , Journal of Economics and International Finance Vol. 1(4), pp. 093-098

17. Qayyum, A. (2006) Money, Inflation, and Growth in Pakistan. The Pakistan Development Review, No.2: pp. 203-212.

18. Rodrik, D. (2008) The Real Exchange Rate and Economic Growth. Harvard University, MA 02138

19. Smyth, D. J. (1992) Inflation and the Growth Rate in the United States. Natural Output. Applied Economics 24: 567-570

20. Smyth, D. J. (1994) Inflation and Growth, Journal of Macroeconomics 16: 261-270.

21. Smyth, D. J. (1995) Inflation and Total Factor Productivity in Germany, Weltwirtschaftliches Archiv, 131: 403-405. 